\title{
The Potential of Fungal Isolates from Vermicompost Water Extract to Inhibit Alternaria solani in Vitro and Suppress Early Blight Disease in Tomato
}

\author{
Noor Istifadah*, Retno Anjani Putri, Fitri Widiantini, Sri Hartati
}

\author{
Faculty of Agriculture, Universitas Padjadjaran, \\ Jl. Raya Bandung-Sumedang Km 21, Jatinangor, Sumedang, West Java, 45363 Indonesia \\ *Corresponding author. Email: $\underline{\text { n.istifadah@unpad.ac.id }}$
}

\begin{abstract}
Early blight disease caused by Alternaria solani, Sorr is an important disease in tomato. Biological control is one of the environmentally-friendly control measures of the disease. Vermicompost is a potential source of antagonistic microbes for biological control of plant diseases. The objective of this study were to isolate fungi from vermicompost water extract and examine their abilities to inhibit the growth of A. solani in vitro and suppress the pathogen infection in tomato fruits and leaves. The fungi were isolated from water extract of two types of vermicompost which were cattle manure vermicompost and goat manure vermicompost. The fungal isolates obtained were tested for their antagonistic abilities against A. solani in vitro using adual culture method. The in vitro experiment was arranged in Completely Randomized Design. The selected isolates were examined their abilities in suppressing A. solani infection in tomato fruits and early blight disease in tomato leaves. The in vivo experiments were arranged in Randomized Complete Block Design. The isolation of fungi from the water extract of two types of vermicompost resulted in 14 fungal isolates, which were nine isolates from cattle manure vermicompost and five isolates from goat manure vermicompost. Among 14 fungal isolates, there were seven isolates that inhibited the growth of $A$. solani in vitro. In tomato fruits, six fungal isolates inhibited $A$. solani infection by $64 \%-76 \%$ at five days after inoculation. However, two isolates (Trichoderma spp.) colonized the fruit surface after seven days of incubation. In tomato plants, two fungal isolates (Trichoderma spp.) suppressed early blight disease in the leaves by 55.3\%-58.2\%. This finding showed that some fungal isolates from the water extract of vermicompost were antagonistic to A. solani in vitro and had potential as the biological control agents of early blight disease in tomato.
\end{abstract}

\section{Keywords: tomato fruit, Trichoderma, biological control, antagonistic microbes}

\section{INTRODUCTION}

Tomato is an important horticultural product required for direct consumption and raw materials for food industries such as tomato sauce. The main problems in tomato cultivation include pests and diseases.

One of important diseases of tomato crop is early blight disease caused by Alternaria solani Sorr. The fungal pathogen infects leaves, petiole, stem, as well as tomato fruits. The infected leaf tissues become necrotic with target spot symptom, surrounded by yellowing or chlorotic tissues. In severe infection the lesions are coalesced and the leaves tissues become dried. In tomato fruit, $A$. solani infection causes dark, sunken lesions, started on the area surrounding the fruit stalk. The infected fruits are easily to drop off. The pathogen infection in tomato crops can cause yield loss up to $79 \%$ [1].

Early blight disease is commonly controlled by pesticide applications. In rainy season the farmers apply the pesticides more intensively. However, it may lead to many negative impacts such as pathogen resistance and accumulation of pesticide residues. Therefore, environmentally friendly control methods such as biological control need to be developed.

One of the microbe sources that potential as biological control agents of plant disease is vermicompost (the product of the decomposition process using earthworm). Organic materials often used in vermicomposting are animal manures such as cattle or goat manures. In addition to its use as organic fertilizer, vermicompost can also be used for controlling plant diseases [2,3]. Vermicompost can be applied directly to the soil as solid form or as water extract for drenching or spraying the plants [2].

The abilities of vermicompost to control plant diseases are mostly due to the presence of antagonistic microbes that inhibit the pathogen [2,4]. Microbes from vermicompost have various useful traits in agriculture. 
They can promote plant growth and therefore can be used for bio-fertilizer. Many of them are also able to inhibit plant pathogens and hence they are potential as biological control agents [4]. This paper discussed the abilities of fungi isolated from water extract of vermicompost (derived from cattle manure and goat manure) in inhibiting the growth of $A$. solani in vitro and controlling the pathogen infection in tomato fruits and early blight disease in tomato plant.

\section{MATERIALS AND METHODS}

\subsection{Isolation of Fungal Isolates}

Filamentous fungi were isolated from water extract of two types of vermicompost which were cattle manurebased vermicompost and goat manure-based vermicompost. The water extract was prepared by mixing the vermicompost with water $1: 4(\mathrm{w} / \mathrm{v})$, stirring the suspension and then it was incubated in a closed lid container for 10 days. The extract was then filtered using cheesecloth.

The fungi were isolated from the vermicompost water extract using serial dilution and pour plating method [5] with half-strength potato dextrose agar containing chloramphenicol $0.05 \%$ as the medium. The fungal isolates with different characteristics were purified.

\subsection{In Vitro Experiment}

The fungal isolates were tested their abilities to inhibit the growth of $A$. solani in vitro using dual culture method, in which culture plug $(0.8 \mathrm{~cm}$ diameter $)$ of fungal isolates and the pathogen were grown in the same agar plate. For check, the pathogen was cultured with agar plug [5]. The growth of the pathogen towards fungal isolate was measured every day until the growth of the pathogen in the check reached the edge of the Petri plates.

The isolates that inhibited the growth of $A$. solani more than $60 \%$ were tested again to confirm their abilities to inhibit the pathogen. The data of this experiment were subjected to statistical analysis using SPSS program version 21.0. The differences between treatments were analysed using Tuckey's HSD test $(\mathrm{p}<0.05)$.

\subsection{In Vivo Experiment}

The isolates that effectively inhibited the growth of A. solani in vitro were selected and tested their effects on the pathogen infection in tomato fruits. The experiment was arranged in a Randomized Complete Block Design (RCBD) with three replications.

Before treatments, the tomato fruits were surface sterilized using ethanol $70 \%$. To facilitate penetration of the pathogen, two spots on the fruit tissues were wounded by the sterile pin. The fungal isolate was applied on those spots, followed by inoculation of culture plug $(0.8 \mathrm{~cm}$ diameter) of the pathogen. The plug was fastened by sticky tape and plastic wrap. The inoculated tomato fruits were incubated in the boxes in which the high humidity was maintained by placing the wet cotton in each box corner. The sticky tape was opened five days after inoculation and the diameter of infected tissue was measured [6].

\subsection{In Planta Experiment}

The experiment was arranged in RCBD with three replications. The treatments tested were selected fungal isolates, the check, and fungicide (active ingredient: carbendazim). The fungal isolates tested were the isolates that effectively inhibiting the pathogen growth in vitro and producing the spores. The sporulation ability was taken into consideration as it is an important trait in mass production of fungal biological control agents.

The conidial suspension (density $10^{7}$ spores $/ \mathrm{mL}$ ) was sprayed onto the tomato leaves. The treated plants were covered with plastic cones for maintaining high humidity and then incubated overnight. The pathogen was inoculated on the treated tomato leaves by placing its culture plug ( $0.8 \mathrm{~cm}$ diameter), fastened with sticky tape. For facilitating the penetration, the spot inoculated with the pathogen was previously wounded with a sterile pin. The inoculated plants were incubated in humid plastic cones for three days. The pathogen inoculum was removed three days after inoculation [6].

The area of infected tissue was measured every day until the disease symptom in the check covered the whole inoculated leaf surface. The data was used to calculate the Area Under Disease Progress Curve (AUDPC) [7].

\section{RESULTS AND DISCUSSION}

\subsection{The Abilities of Fungal Isolates to Inhibit A. solani in Vitro}

Total of 14 fungal isolates were successfully isolated from vermicompost water extract. They were nine isolates from cattle manure vermicompost and five isolates from goat manure vermicompost. Among the isolates, there were seven isolates that inhibited the growth of $A$. solani more than $60 \%$ (Figure 1).

The isolates were then further tested to confirm their antagonistic effects on the pathogen. The results of further test showed that seven selected isolates inhibited the growth of $A$. solani by $63.8 \%-81.9 \%$ (Table 1). This result confirmed previous test which also found similar results. The genera of the selected fungal isolates found from vermicompost in this study were also found in vermicompost in previous study [8].

Isolate that showed relatively better disease suppression was SJ6 isolate. Based on its characteristics particularly the colony, conidiophore and conidia, the isolate was identified as Trichoderma sp. The antagonistic 
abilities of Trichoderma spp. against A. solani have already been reported $[9,10]$. The inhibition of pathogen by Trichoderma could be due to several mechanisms such as competition of space and nutrition, production of secondary metabolites volatile or non-volatile compounds that are toxic to the pathogen, and also hyperparasitism [11].

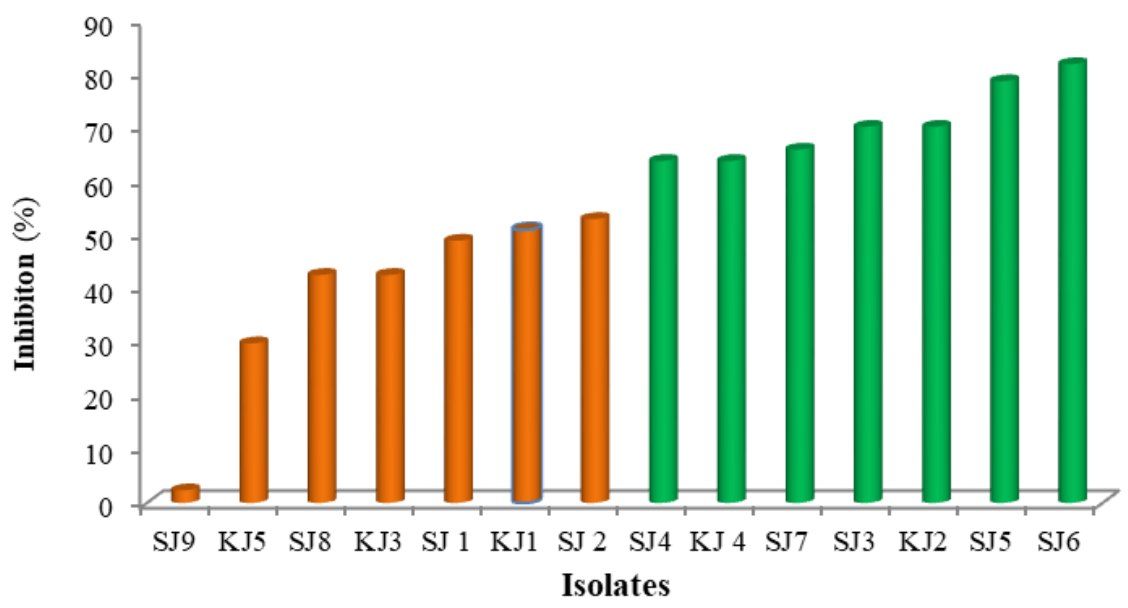

Figure 1 The level of growth inhibition of $A$. solani due to the fungal isolates

Table 1 The effects of the selected fungal isolates on A. solani growth in vitro

\begin{tabular}{|l|c|c|}
\hline \multicolumn{1}{|c|}{ Treatments } & $\begin{array}{c}\text { Radial of pathogen colony towards } \\
\text { the tested fungi (mm) }\end{array}$ & Inhibition (\%) \\
\hline Check & $15,7 \mathrm{~d}$ & 0,0 \\
\hline KJ 2 isolate (Beauveria sp.) & $4,7 \mathrm{abc}$ & 70,2 \\
\hline KJ 4 isolate (Fusarium sp.) & $5,7 \mathrm{c}$ & 63,8 \\
\hline SJ 3 isolate (no spore produced) & $4,7 \mathrm{abc}$ & 70,2 \\
\hline SJ 4 isolate (Cladosporiumsp) & $5,7 \mathrm{c}$ & 63,8 \\
\hline SJ 5 isolate (Trichoderma $\mathrm{sp})$. & $3,3 \mathrm{ab}$ & 78,7 \\
\hline SJ 6 isolate (Trichoderma $\mathrm{sp}$.) & $2,8 \mathrm{a}$ & 61,9 \\
\hline SJ 7 isolate (no spore produced) & $5,3 \mathrm{bc}$ & 65,9 \\
\hline
\end{tabular}

Data in one column followed by different letters were significantly different $(p<0.05)$ based on Tuckey HSD test

\subsection{The Abilities of the Fungal Isolates to Inhibit A. solani Infection in Tomato Fruits}

In this experiment, the inoculated fruits started to decay five days after the pathogen inoculation. In the fungal isolate treatment, the diameter of the decay was smaller than the decay in the check. The fungal isolate tested inhibited A. solani infection in tomato fruits by $64 \%-76 \%$ (Table 2). In the treatment using Trichoderma spp. (SJ5 and SJ6 isolates), even though the fungi reduced the diameter of the decay due to $A$. solani, however, the colony of Trichoderma covered the infected tissues seven days after the pathogen inoculation. Trichoderma is saprophytic fungus, so in the humid condition it can colonize the rotted tissues. These results were differed to other studies that used Trichoderma as biological control of postharvest disease in fruits such as mango, banana, and papaya [12].

Table 2 The effects of fungal isolates on A. solani infection on tomato fruits

\begin{tabular}{|l|c|c|}
\hline \multicolumn{1}{|c|}{ Treatments } & AUDPC value & Suppression(\%) \\
\hline Check & $5.0 \mathrm{~b}$ & 00.0 \\
\hline KJ 2 isolate (Beauveria sp.) & $1.8 \mathrm{a}$ & 64.0 \\
\hline KJ 4 isolate (Fusarium sp.) & $1.7 \mathrm{a}$ & 66.0 \\
\hline SJ 3 isolate (no spore produced) & $1.3 \mathrm{a}$ & 74.0 \\
\hline SJ 4 isolate (Cladosporiumsp) & $1.2 \mathrm{a}$ & 76.0 \\
\hline SJ 5 isolate (Trichoderma sp.) & $1.2 \mathrm{a}$ & 76.0 \\
\hline SJ 6 isolate (Trichoderma sp.) & $1.5 \mathrm{a}$ & 70.0 \\
\hline SJ 7 isolate (no spore produced) & $1.3 \mathrm{a}$ & 74.0 \\
\hline
\end{tabular}

Data in one column followed by different letters were significantly different $(p<0.05)$ based on Tuckey HSD test 
The difference on the Trichoderma performance may be due to the difference on the Trichoderma species and also the kinds of the fruits. In other study, Trichoderma was reported to be pathogenic and caused tangerine fruit rot [13].

\subsection{The Abilities of the Fungal Isolates to Inhibit Early Blight Disease in Tomato Leaves}

In this experiment, the necrotic lesion on the pathogen inoculated leaves started to appear five days after inoculation (Table 3). The application of fungal isolates before the pathogen inoculation inhibited the development of the disease by $24.8 \%-58.2 \%$. Among the isolates tested, Trichoderma spp. suppressed early blight disease by 55.5\%-58.2\%. The abilities of Trichoderma spp. to suppress foliar diseases including the disease caused by $A$. solani have been reported in other studies $[9,11]$. Adiba and Escow [9] reported that the application of Trichoderma as a foliar spray or soil drenching suppressed early blight disease caused by $A$. solani in potato. This result indicated that mechanism of Trichoderma to suppress plant disease can be due to direct antagonism such as competition, antibiosis as well as due to induction of host resistance [11]

Table 3 The effects of fungal isolates on early blight disease (A. solani) in tomato leaves

\begin{tabular}{|l|c|c|}
\hline \multicolumn{1}{|c|}{ Treatments } & AUDPC value & Disease Suppression (\%) \\
\hline Check & $9.9 \mathrm{a}$ & 0.0 \\
\hline KJ 2 isolate (Beauveria sp.) & $6.4 \mathrm{~b}$ & 35.3 \\
\hline KJ 4 isolate (Fusarium sp.) & $7.3 \mathrm{~b}$ & 24.8 \\
\hline SJ 4 isolate (Cladosporium sp. ) & $5.2 \mathrm{c}$ & 47.0 \\
\hline SJ 5 isolate (Trichoderma sp.) & $4.1 \mathrm{c}$ & 58.2 \\
\hline SJ 6 isolate (Trichoderma sp.) & $4.4 \mathrm{c}$ & 55.3 \\
\hline Pesticide (mancozeb) & $2.9 \mathrm{~d}$ & 70.9 \\
\hline
\end{tabular}

Data in one column followed by different letters were significantly different $(p<0.05)$ based on Tuckey HSD test

Overall results of this study showed that fungal isolates from vermicompost water extract had potential as biological control agent of early blight disease in tomato. The isolates that showed relatively sufficient suppression of early blight disease in tomato plant were Trichoderma spp. However, the use of the fungal isolates for controlling postharvest disease in tomato fruits is risky as in the humid condition they may sporulation on the rotted or damaged tomato tissues.

In this study, the efficacies of the selected isolates in suppressing early blight disease in tomato were still less than $60 \%$. To improve the control effects, the use of these biological control agents can be integrated with other compatible control measures such as the use of resistant variety, the use of organic matters and other cultural techniques.

\section{CONCLUSION}

Among 14 fungal isolates from vermicompost water extract, there were seven isolates that inhibited the growth of $A$. solani in vitro by $63.8-81.9 \%$. In tomato fruits, six fungal isolates inhibited $A$. solani infection by $64 \%-76 \%$ at five days after inoculation. In tomato plants, two fungal isolates (Trichoderma spp.) suppressed early blight disease in the leaves by $55.3 \%-58.2 \%$.

\section{ACKNOWLEDGMENT}

This study is part of research under scheme PDUPT funded by DRPM, Ministry of Research and
Technology Directorate General of Higher Education, Republic of Indonesia.

\section{REFERENCES}

[1] N. Gulzar , A.N. Kamili, M.Y. Mir, 'The process of early blight disease development in tomato', $J$. Res. Dev. vol. 18, pp. 112-115, 2018.

[2] Y. Simsek-Ersahin, 'The use of vermicompost products to control plant disease and pests'. In A. Karaca (ed.) Biology of Earthworms. SpringerVerlag Berlin Heidelberg, pp. 191-213, 2010. DOI: 10.1007/978-3-642-14636-7_12.

[3] B. K. Sarma, S. K. Pandey, P. Singh, H. B. Singh, 'Vermicompost as modulator of plant growth and disease suppression', Dyn Soil Dyn Plant, vol. 4, no. 1 , pp. 58-66, 2010

[4] J. Pathma and N. Sakthivel, 'Microbial diversity of vermicompost bacteria that exhibit useful agricultural traits and waste management potential', Springer Plus, 1: 26 , 2012. https://doi.org/10.1186/2193-1801-1-26

[5] O. D. Dhingra, J. B. Sinclair, 'Basic Plant Pathology Methods'. Second edition, Lewis Publishers, Boca Raton, 1995.

[6] N. Istifadah, P. G Novilaressa, F. Widiantini, S. Hartati, 'Keefektifan bakter dan khamir asal air rendaman kompos dalam menekan perkembangan penyakit bercak coklat (Alternaria solani Sorr.) 
pada tomat', J. Agrikultura, vol. 31, no. 1, pp. 5260, 2020.

[7] L. C. Campbell, V. L. Madden, 'Introduction Plant Disease Epidemiology'. John Wiley and Son, USA, 1990.

[8] A. Anastasi, G. C. Varese, V. F Marchisio, 'Isolation and identification of fungal communities in compost and vermicompost', Mycologia, vol. 97, no. 1, pp. 33-44, 2005.

[9] A. Aldiba, I. Escov, 'Biological control of early blight on potato caused by Alternaria solani by some bioagents', Advances in Biological Sciences Research, vol. 7, pp. 1-5, 2019. https://doi.org/10.2991/isils-19.2019.1

[10] M. U. Ghazanfar, M. Raza, W. Raza, 'Efficacy of Trichoderma isolates as biocontrol agent against
Alternaria solani', Int. J. Botany Stud, vol. 4, no. 2, pp. 136-143, 2019.

[11] I. S. Sawant, 'Trichoderma-foliar pathogen interactions', Open Mycol J., vol. 8, pp. 58 -70, 2014.

[12] L. Fenta, H. Mekonnen, T. Gashaw, 'Biocontrol potential of Trichoderma and yeast against postharvest fruit fungal diseases: A review, World News Nat. Sciences, vol. 27, pp. 153-173, 2019.

[13] C. Hu, M. A. Ritenour, E. Rosskopf, 'Trichoderma rot on 'Fallgio' tangerine fruit in Florida', Proc. Fla. State Hort. Soc., vol. 124, pp. 232-234, 2011. 